\title{
Seleksi Mutan Tanaman Lamtoro (Leucaena leucocephala cv. Tarramba) Tahan Kutu Loncat terhadap Lingkungan Kering pada Rumah Kaca
}

Mutant Selection of Lamtoro (Leucaena leucocephala cv. Tarramba) on Dry Environment in Green House

R Anggriani, P D M H Karti, I Prihantoro

\section{Corresponding email:}

rinianggriani454@gmail.com

Departemen Ilmu Nutrisi dan

Teknologi Pakan, Fakultas

Peternakan, IPB University, Jl. Agatis Kampus IPB Dramaga, Bogor, Indonesia

Submitted: $26^{\text {th }}$ July 2021 Accepted : $10^{\text {th }}$ November 2021

\section{ABSTRACT}

Forage is the main source of feed for ruminants. Forage consists of two types, namely grass and legumes. Leguminosa is a type of forage as a source of protein. One type of legume that is well known by breeders in Indonesia is lamtoro (Leucaena leucocephala cv. Tarramba). This study was aimed to produce candidate mutants of lamtoro drought resistant to acid stress conditions. The experiment in this study used an unbalanced completely randomized design with 6 treatments of 740 different replications based on different sources of lamtoro plant mutants at different levels (P0: $0 \mathrm{n}=89, \mathrm{P} 1: 100$ gy $n=82, P 2: 200$ gy $n=153, P 3: 300$ gy $n=120, P 4: 400$ gy $n=244, P 5: 500$ gy $n=52$ ). Variables observed included plant height, number of stalks, leaf loss and stem diameter. The results showed that lamtoro plants irradiated with gamma rays at a level of 200 gy500 gy were significantly higher than 100 gy irradiation at 10 and 12 days watering, but the diameter of the plants was larger at 100 gy irradiation. It can be watering intervals of 10 days and 12 days on the parameters of height and stem diameter showed that gamma rays irradiation of 400 gy resulted in dry-resistant lamtoro mutant candidates under acid stress condition.

Key words: gamma rays, lamtoro mutant, watering interval

\section{ABSTRAK}

Leguminosa merupakan jenis hijauan pakan sumber protein. Salah satu jenis leguminosa yang telah dikenal baik oleh peternak di Indonesia adalah lamtoro (Leucaena leucocephala) varietas Tarramba. Penelitian ini bertujuan untuk menghasilkan kandidat mutan lamtoro (Leucaena leucocephala cv. Tarramba) tahan kering terhadap kondisi cekaman masam. Rancangan percobaan menggunakan RAL Tak Seimbang dengan 6 perlakuan 740 ulangan berbeda berdasarkan perbedaan sumber mutan tanaman lamtoro (Leucaena leucocephala cv. Tarramba) pada level yang berbeda ( P0: 0 gy n= 89, P1: 100 gy $n=82, P 2: 200$ gy $n=153$, P3:300 gy n=120, P4: 400 gy $n=244$, P5: 500 gy $n=52$ ) dengan interval penyiraman 10 hari dan 12 hari. Variabel yang diamati meliputi tinggi tanaman, jumlah tangkai, kerontokan daun dan diameter batang. Hasil penelitian menunjukkan bahwa tanaman lamtoro yang disinari sinar gamma dengan level 200 gy- 500 gy nyata lebih tinggi dibandingkan dengan penyinaran 100 gy pada penyiraman 10 hari dan 12 hari tetapi diameter tanaman yang lebih besar pada penyinaran 100 gy. Kesimpulan dari penelitian ini adalah tinggi tanaman lamtoro yang disinari sinar gamma 200 gy, 300 gy dan 400 gy dan 500 gy nyata lebih tinggi $(\mathrm{p}<0,05)$ dibandingkan dengan 100 gy. Kesimpulan dari penelitian ini yaitu pada interval penyiraman 10 hari dan 12 hari pada tinggi dan diameter batang menunjukkan iradiasi sinar gamma 400 gy menghasilkan kandidat mutan lamtoro tahan kering terhadap kondisi cekaman masam.

Kata kunci: interval penyiraman, mutan lamtoro, sinar gamma 


\section{PENDAHULUAN}

Mutasi adalah perubahan materi genetik, yang diwariskan serta merupakan sumber pokok dari semua keragaman genetik dan merupakan bagian dari fenomena alam. Jika mutasi terjadi pada sel somatik, maka perubahan hanya pada bagian itu dan tidak diwariskan, namun apabila mutasi terjadi pada sel generatif, maka dapat diwariskan pada generasi berikutnya (Poespadorsono, 1998). Perubahan dapat terjadi pada tingkat pasangan basa, tingkat satu ruas DNA, bahkan pada tingkat kromosom.

Dosis iradiasi yang digunakan untuk menginduksi keragaman sangat menentukan keberhasilan terbentuknya tanaman mutan. Induksi mutasi merupakan salah satu cara yang sering digunakan para peneliti sebagai usaha untuk memperoleh tanaman yang lebih tahan terhadap suatu penyakit. Fitri (2010), Kisaran dosis iradiasi yang efektif pada benih umumnya lebih tinggi jika dibandingkan dengan bagian tanaman lainnya. Semakin banyak kadar oksigen dan molekul air (H20) dalam materi yang diiradiasi, maka akan semakin banyak pula radikal bebas yang terbentuk, sehingga tanaman menjadi lebih sensitif (Herison et al. 2008). Dalam bidang pemuliaan tanaman, mutasi buatan sering dipakai untuk meningkatkan keragaman genetik dalam perakitan varietas baru. Sinar gamma merupakan mutagen yang paling banyak digunakan dalam memproduksi varietas mutan (Soeranto, 2003). Radiasi sinar gamma merupakan radiasi ionisasi. Bentuk radiasi ini dapat menembus sel-sel dan jaringan dengan mudah.

Kendala yang dihadapi budidaya lamtoro di lahan kering Indonesia adalah cekaman tanah masam, karena jenis tanah ini sangat luas, yaitu mencapai 99,5 juta ha. Tanah bereaksi masam dengan indikator utama pH tanah kurang dari 5,0 mengakibatkan kelarutan Aluminium (Al) tinggi dalam tanah sehingga menjadi racun bagi tanaman. Cekaman $\mathrm{Al}$ menyebabkan gangguan pertumbuhan akar sehingga penyerapan hara dan air menjadi terhambat (Marchner, 1995) dan menjadi salah satu faktor pembatas pertumbuhan dan produksi tanaman di tanah masam (Jones \& Kochian, 1995).

Pengembangan varietas toleran tanah masam adalah salah satu alternatif untuk meningkatkan efisiensi budidaya di tanah masam. Pengembangan sorgum toleran tanah masam dengan produktivitas tinggi diawali dengan melakukan seleksi terhadap galurgalur hasil mutasi fisika yang telah dilakukan oleh Badan Tenaga Nuklir Nasional (BATAN). Keragaman genetik dari galur tersebut diperoleh dari induksi mutasi dengan meradiasi benih lamtoro dengan sinar Gamma yang bersumber dari Cobalt-60. Pembentukan galur mutan ini bertujuan untuk memperbaiki karakter agronomi dan kualitas hasil lamtoro sehingga sesuai dengan kondisi agroekologi yang diinginkan (Hoeman, 2007).

Hijauan pakan ternak merupakan sumber pakan utama bagi ternak ruminansia yang memberikan manfaat untuk pertumbuhan dan perkembangbiakan ternak tersebut. Secara umum, kualitas dan produktivitas hijauan pakan di daerah tropis masih sangat relatif rendah. Pemanenan hijauan dan leguminosa pada masa vegetatif tanaman berupa bagian hijauan yang meliputi daun, batang dan kemungkinan juga sedikit tercampur bagian generatif adalah sebagai sumber makanan ternak ruminansia (Reksohadiprojo, 1987).

Leguminosa merupakan jenis hijauan pakan sumber protein. Salah satu jenis leguminosa yang telah dikenal baik oleh peternak di Indonesia adalah lamtoro (Leucaena leucocephala) varietas Tarramba. Tanaman lamtoro memiliki kandungan protein kasar yang tinggi yakni sebesar 23,7\%-34\% dengan palatabilitas yang tinggi (Yumiarty \& Suradi, 2010). Lamtoro merupakan salah satu hijauan pakan ternak yang mampu beradaptasi dengan baik di daerah tropis. Selain itu, lamtoro mampu beradaptasi pada tanah dengan kemasaman sedang antara pH 5,5 - 6,5 dan beriklim sedang dengan curah hujan tahunan diatas $760 \mathrm{~mm}$ (Hoult \& Briant 1974). Lamtoro (Leucaena leucocephala) varietas Tarramba memiliki tingkat ketahanan terhadap hama kutu loncat (Hettepsylla cubana Crawford atau Hettepsylla insica Sulc) menurut Yasin (2006) menyatakan tingkat kerusakan tanaman lamtoro akibat kutu loncat berbeda antara tanaman muda dan tanaman dewasa serta kekekaran tanaman sangat mempengaruhi toleransi terhadap serangan serangga. Meskipun demikian lamtoro (Leucaena leucocephala cv. Tarramba) memiliki tingkat adaptasi yang kurang baik dengan tanah masam.

Informasi tentang pewarisan karakter agronomi lamtoro ketika ditanam di tanah masam serta melakukan seleksi terhadap galur-galur mutan yang dikembangkan oleh BATAN sehingga diperoleh beberapa galur mutan harapan yang toleran terhadap tanah masam dengan produktivitas dan kualitas tinggi. Tujuan penelitian ini adalah mendapatkan mutan tanaman lamtoro cv Tarramba tahan terhadap hama kutu loncat serta tahan terhadap kekeringan

\section{METODE}

\section{Alat dan Bahan}

Alat yang digunakan pada penelitian ini adalah jangka sorong, polybag, peralatan pengamatan dan peralatan penyiraman dan bahan yang digunakan adalah mutan lamtoro (Leucaena leucocephala cv.Tarramba) tahan kutu loncat (Hettepsylla Cubana Crawford atau Hettepsylla insica Sulc) pada tanah masam kejenuhan aluminium tinggi dengan $\mathrm{pH}$ 5,3.

Bahan yang digunakan adalah mutan lamtoro (Leucaena leucocephala cv.Tarramba) tahan kutu loncat (Hettepsylla Cubana Crawford atau Hettepsylla Insica Sulc) yang ditanam menggunakan media tanah masam kejenuhan aluminium tinggi dengan $\mathrm{pH}$ 5,3. 


\section{Prosedur Penelitian \\ Daya tumbuh dan radiosensivitas tanaman lamtoro pasca iradiasi sinar gamma}

Benih lamtoro di seleksi untuk mendapatkan benih terbaik kemudian diiradiasi dengan sinar gamma Chamber 4000Å (aktivitas Co60 721.201Ci; dengan dosis 0.57 gy per menit) setelah diiradiasi diberikan seed treatment pada larutan klorok selama 10 menit kemudian direndam dalam aquadest selama 5 menit selanjutnya direndam kembali dengan air hangat selama 5 menit kemudian yang terakhir direndam dalam air biasa selama 8 jam. Benih yang telah direndam kemudian diangin-anginkan kemudian ditanam pada polybag ukuran $10 \mathrm{~cm} \times 15 \mathrm{~cm}$ yang berisi tanah latosol dan kompos (1:1) sebanyak 740 polybag.

Respon pertumbuhan tanaman lamtoro pasca iradiasi sinar gamma pada tanah latosol

Tanaman yang telah berumur 21 hari kemudian diseleksi dan dilakukan pemeliharaan. Pengamatan respon pertumbuhan tanaman dilakukan setiap minggu selama 1 bulan.

Respon pertumbuhan tanaman lamtoro pasca iradiasi sinar gamma pada tanah masam dengan kejenuhan alumium tinggi

Tanaman berumur 45 hari setelah tanam (HST) diseleksi dari serangan hama penyakit serta tidak kerdil lalu tanaman dipindahkan pada polybag berukuran $20 \mathrm{~cm} \mathrm{x}$ $25 \mathrm{~cm}$ dengan media tanah masam kejenuhan almunium tinggi dengan $\mathrm{pH}$ 5,3.

Seleksi mutan tanaman lamtoro (Leucaena Leucocephala Cv.Tarramba) tahan kutu loncat (Hettepsylla Cubana Crawford atau Hettepsylla Insica Sulc) dan tahan kering pada rumah kaca.

Tanaman diseleksi (tidak kerdil dan tidak terserang hama kutu loncat). Pengamatan tanaman dilakukan selama 1 bulan setiap interval penyiraman.

Manajemen pemeliharaan dikelompokan berdasarkan perlakuan 0, $100 \mathrm{gy}, 200 \mathrm{gy}, 300 \mathrm{gy}, 400$ gy dan 500 gy

Pemeliharaan meliputi penyiraman dilakukan setiap 10 hari sekali selama 4 minggu dan 12 hari sekali selama 4 minggu. Penyiangan (wedding) dilakukan pencabutan gulma secara manual.

\section{Rancangan Percobaan dan Analisis Data}

Rancangan dan analisis data yang digunakan adalah RAL tidak seimbang dengan 6 perlakuan 740 ulangan berbeda berdasarkan perbedaan sumber mutan tanaman lamtoro (Leucaena leucocephala cv. Tarramba) pada level yang berbeda ( P0: 0 n= 89, P1: 100 gy $n=82, P 2: 200$ gy $n=$ $153, \mathrm{P} 3: 300$ gy $n=120, \mathrm{P} 4: 400$ gy $n=244, \mathrm{P} 5: 500$ gy $n=$ 52). Selanjutnya jika terdapat perbedaan yang nyata akan dilakukan uji lanjut Duncan pada taraf 5\% (Steel Torrie, 1995).

\section{HASIL DAN PEMBAHASAN}

Karakteristik Mutan Tanaman Lamtoro Teradaptasi Kutu Loncat dengan Interval Penyiraman 10 Hari Tinggi tanaman

Pada Tabel 1 terlihat pemberian dosis sinar gamma berbeda berpengaruh terhadap pertambahan tinggi tanaman. Respon tinggi mutan tanaman lamtoro teradaptasi kutu loncat dengan interval penyiraman 10 hari dengan dosis sinar gamma berbeda menunjukan pengaruh yang nyata $(p<0,05)$ lebih rendah pada level penyinaran 100 gy dibandingkan level penyinaran lainnya. Hal ini disebabkan karena pemberian sinar gamma dapat mempengaruhi pertumbuhan serta perkembangan tanaman secara fisiologi, genetik maupun morfologi sel tumbuhan sehingga memberikan pengaruh kurang baik pada pertumbuhan tinggi tanaman level 100 gy.

Rici (2009) menyatakan bahwa semakin tinggi dosis radiasi yang diberikan pada tanaman kedelai maka akan semakin besar pula tingkat kerusakan dan penghambatan pertumbuhan tanaman. Perubahan yang sama terjadi pada tanaman kedelai yang mengalami penurunan tinggi tanaman ketika mendapat perlakuan iradiasi dengan dosis yang semakin tinggi (Hanafiah et al. 2010).

\section{Jumlah tangkai}

Pada Tabel 1 terlihat respon jumlah tangkai mutan tanaman lamtoro dengan level penyinaran berbeda. Level penyinaran sinar gamma yang berbeda nyata $(p<0,05)$ mempengaruhi jumlah tangkai. Jumlah tangkai pada mutan tanaman lamtoro teradaptasi kutu loncat dengan interval penyiraman 10 hari dengan dosis sinar gamma berbeda pada 14 MST menunjukan pengaruh yang nyata lebih rendah pada level 200 gy dengan level lainnya, kemudian 15 MST, 16 MST dan 17 MST pada 400 gy nyata lebih baik daripada 200 gy.

\section{Kerontokan daun}

Pemberian dosis sinar gamma berbeda nyata mempengaruhi kerontokan daun tanaman (Tabel 1). Dosis penyinaran sinar gamma yang berbeda tidak memberikan pengaruh pada kerontokan daun 14 MST dan 15 MST karena pada saat umur 14 MST dan 15 MST masih pada fase vegetatif sehingga daun masih dalam keadaan muda dan segar. Adanya perubahan morfologi sebagai akibat terjadinya kerusakan pada kromosom daun sehingga proses fotosintesis menjadi terganggu.

\section{Diameter batang tanaman}

Pemberian dosis sinar gamma berbeda berpengaruh terhadap diameter tanaman (Tabel 1). Level 500 gy pada umur 14 MST menghasilkan diameter tanaman yang lebih baik daripada perlakuan level 300 gy hal ini sejalan dengan penelitian Serviana (2019) dengan dosis radiasi 20 gy merupakan dosis yang memiliki rata-rata diameter batang tertinggi, dosis radiasi 10 gy memiliki rerata diameter tertinggi kedua dan rerata diameter terendah terjadi pada dosis radiasi 30 gy, sedangkan pada 15 MST 
Tabel 1 Respon tanaman lamtoro (Leucaena leucocephala Cv.Tarramba) terhadap interval penyiraman 10 hari

\begin{tabular}{|c|c|c|c|c|c|}
\hline \multirow{2}{*}{$\begin{array}{c}\text { Minggu } \\
\text { Ke- }\end{array}$} & \multicolumn{5}{|c|}{ Mutan Tanaman Lamtoro (Leucaena leucocephala Cv. Tarramba) } \\
\hline & G100 & G200 & G300 & G400 & G500 \\
\hline \multicolumn{6}{|c|}{ Tinggi Tanaman } \\
\hline $14 \mathrm{MST}$ & $78,54 \pm 7,58^{b}$ & $83,79 \pm 14,16^{a}$ & $84,65 \pm 13,12^{a}$ & $82,66 \pm 12,36^{a}$ & $84,28 \pm 10,56^{a}$ \\
\hline $15 \mathrm{MST}$ & $78,27 \pm 7,64^{b}$ & $83,26 \pm 15,37^{a}$ & $84,60 \pm 13,11^{a}$ & $82,49 \pm 12,37^{a}$ & $84,29 \pm 10,58^{a}$ \\
\hline $16 \mathrm{MST}$ & $78,34 \pm 7,63^{b}$ & $83,47 \pm 15,34^{a}$ & $84,94 \pm 13,15^{a}$ & $82,65 \pm 12,40^{a}$ & $84,40 \pm 10,53^{a}$ \\
\hline $17 \mathrm{MST}$ & $78,38 \pm 7,64^{b}$ & $83,59 \pm 15,33^{a}$ & $85,90 \pm 11,36^{a}$ & $82,69 \pm 12,40^{a}$ & $84,44 \pm 10,52^{\mathrm{a}}$ \\
\hline \multicolumn{6}{|c|}{ Jumlah Tangkai } \\
\hline $14 \mathrm{MST}$ & $16,12 \pm 3,08^{a}$ & $14,88 \pm 2,93^{b}$ & $16,34 \pm 2,55^{a}$ & $16,70 \pm 3,06^{a}$ & $15,85 \pm 2,89^{a}$ \\
\hline $15 \mathrm{MST}$ & $16,10 \pm 3,07^{a b}$ & $14,88 \pm 2,93^{c}$ & $16,34 \pm 2,55^{\mathrm{ab}}$ & $16,70 \pm 3,06^{a}$ & $15,73 \pm 2,74^{b}$ \\
\hline $16 \mathrm{MST}$ & $17,56 \pm 2,85^{\mathrm{ab}}$ & $15,46 \pm 3,06^{c}$ & $17,90 \pm 2,36^{a b}$ & $18,19 \pm 2,78^{a}$ & $17,25 \pm 2,61^{b}$ \\
\hline $17 \mathrm{MST}$ & $19,11 \pm 2,53^{\mathrm{ab}}$ & $16,84 \pm 2,73^{c}$ & $19,67 \pm 2,16^{a}$ & $19,77 \pm 2,48^{a}$ & $18,69 \pm 2,56^{b}$ \\
\hline \multicolumn{6}{|c|}{ Kerontokan Daun } \\
\hline $14 \mathrm{MST}$ & $1,56 \pm 0,57$ & $1,45 \pm 0,51$ & $1,48 \pm 0,55$ & $1,50 \pm 0,52$ & $1,50 \pm 0,54$ \\
\hline $15 \mathrm{MST}$ & $1,38 \pm 0,49$ & $1,37 \pm 0,48$ & $1,38 \pm 0,49$ & $1,43 \pm 0,50$ & $1,37 \pm 0,49$ \\
\hline $16 \mathrm{MST}$ & $1,51 \pm 0,50^{\mathrm{ab}}$ & $1,50 \pm 0,50^{\mathrm{abc}}$ & $1,36 \pm 0,48^{c}$ & $1,41 \pm 0,49^{b c}$ & $1,60 \pm 0,50^{a}$ \\
\hline $17 \mathrm{MST}$ & $1,41 \pm 0,50^{\mathrm{bc}}$ & $1,45 \pm 0,50^{b}$ & $1,63 \pm 0,49^{a}$ & $1,47 \pm 0,50^{b}$ & $1,29 \pm 0,46^{c}$ \\
\hline \multicolumn{6}{|c|}{ Diameter Batang Tanaman } \\
\hline $14 \mathrm{MST}$ & $5,44 \pm 0,58^{\mathrm{abc}}$ & $5,50 \pm 0,66^{\mathrm{ab}}$ & $5,31 \pm 0,67^{c}$ & $5,35 \pm 0,63^{b}$ & $5,60 \pm 0,57^{a}$ \\
\hline $15 \mathrm{MST}$ & $6,04 \pm 5,57$ & $5,50 \pm 0,66$ & $5,31 \pm 0,67$ & $5,35 \pm 0,63$ & $5,60 \pm 0,57$ \\
\hline $16 \mathrm{MST}$ & $6,14 \pm 5,57$ & $5,53 \pm 0,66$ & $5,38 \pm 0,70$ & $5,40 \pm 0,62$ & $5,63 \pm 0,56$ \\
\hline $17 \mathrm{MST}$ & $6,23 \pm 5,56^{a}$ & $5,58 \pm 0,66^{b}$ & $5,42 \pm 0,69^{b}$ & $5,47 \pm 0,63^{b}$ & $5,68 \pm 0,57^{a b}$ \\
\hline
\end{tabular}

G100 = dosis sinar gamma 100 gy, G200 = dosis sinar gamma 200 gy, G300 = dosis sinar gamma 300 gy, G400 = dosis sinar gamma 400 gy, G500 = dosis sinar gamma 500 gy. MST (Minggu Setelah Tanam). Superskrip yang berbeda pada baris yang sama menunjukkan berbeda nyata (p<0,05)

dan 16 MST tidak memberikan pengaruh yang berbeda pada semua perlakuan dan pada 17 MST 100 gy memberikan diameter tanaman lebih baik daripada 300 gy. Hal ini karena pemberian dosis radiasi yang terlalu tinggi akan menghambat pembelahan sel dan kematian sel yang sangat berpengaruh terhadap proses pertumbuhan tanaman, menurunnya daya tumbuh dan morfologi tanaman. Namun demikian, pemberian dosis yang terlalu rendah tidak cukup untuk memutasi tanaman karena frekuensi mutasi yang terlalu rendah hanya menghasilkan sedikit sektor yang termutasi Hammed, 2008).

\section{Karakteristik Mutan Tanaman Lamtoro Teradaptasi Kutu Loncat dengan Interval Penyiraman 12 Hari Tinggi tanaman}

Berdasarkan hasil pengamatan diketahui bahwa pemberian dosis sinar gamma berbeda berpengaruh terhadap pertambahan tinggi tanaman. Hasil analisis ragam pengukuran pertambahan tinggi Tanaman pada Tabel 2. Karakteristik mutan tanaman lamtoro tahan kutu loncat pada skala rumah kaca berdasarkan perbedaan dosis penyinaran sinar gamma interval penyiraman 12 hari memberikan pengaruh yang nyata paling rendah pada level 100 gy dibandingkan dengan level lainnya. Tanaman lamtoro yang disinari penyinaran level yang lebih besar menghasilkan tanaman yang lebih tinggi. Hal ini lebih baik dari penelitian (Purba 2015) Dosis iradiasi pempengaruhi karakter tinggi tanaman jahe putih kecil pada dosis iradiasi umur 2, 3, 4 BST mengalami penuruan tinggi.

\section{Jumlah tangkai mutan tanaman}

Pemberian dosis sinar gamma berbeda berpengaruh terhadap jumlah tangkai tanaman disajikan pada Tabel 2.
Level penyinaran 300 gy dan 400 gy menghasilkan jumlah tangkai paling banyak dibandingkan perlakuan lainnya. Sibarani (2015) menyatakan bahwa pada dosis 300 gy berbeda nyata terhadap kontrol. Adapun perlakuan penyinaran 200 gy nyata menghasilkan jumlah tangkai paling rendah hal ini lebih baik dari penelitian Sibarani (2015) menyatakan bahwa pada dosis 200 gy berbeda tidak nyata terhadap kontrol

\section{Kerontokan daun mutan tanaman}

Pemberian dosis sinar gamma berbeda tidak berpengaruh terhadap kerontokan daun tanaman yang disajikan pada Tabel 2. Level penyinaran 300 gy dapat memberikan rataan kerontokan daun tanaman yang relatif tinggi berdasarkan umur tanaman lamtoro 18 MST. Level penyinaran 500 gy memberikan rataan kerontokan daun tanaman yang relatif rendah berdasarkan umur tanaman lamtoro.

\section{Diameter batang mutan tanaman}

Pemberian dosis sinar gamma berbeda tidak berpengaruh terhadap diameter tanaman, kecuali pada umur 1 minggu setelah tanam disajikan pada Tabel 2 . Diameter batang tanaman lamtoro umur 18 MST pada level 100 gy memberikan pengaruh paling baik di bandingkan dengan level lainnya hal ini dikarenakan pemberian dosis rendah memberikan pengaruh pada metabolism tanaman Hal ini sesuai dengan pendapat Metwally et al. (2015) menyatakan iradiasi memberikan efek perubahan struktur seluler tanaman, metabolisme dan fotosintesis. Pengaruh dosis penyinaran tidak ada terhadap karakter morfologi lain diduga karena tingkat radiosensitivitas yang rendah sehingga tidak adanya perubahan materi genetik yang menyebabkan mutase. 
Tabel 2 Respon tanaman lamtoro (Leucaena leucocephala Cv.Tarramba) terhadap interval penyiraman 12 hari

\begin{tabular}{|c|c|c|c|c|c|}
\hline \multirow{2}{*}{$\begin{array}{c}\text { Minggu } \\
\text { Ke- }\end{array}$} & \multicolumn{5}{|c|}{ Mutan Tanaman Lamtoro (Leucaena leucocephala Cv. Tarramba) } \\
\hline & G100 & G200 & G300 & G400 & G500 \\
\hline \multicolumn{6}{|c|}{ Tinggi Tanaman } \\
\hline $18 \mathrm{MST}$ & $78,38 \pm 7,64^{b}$ & $83,59 \pm 15,33^{a}$ & $85,90 \pm 11,36^{a}$ & $82,69 \pm 12,40^{a}$ & $84,44 \pm 10,52^{a}$ \\
\hline 19 MST & $78,34 \pm 7,65^{b}$ & $83,63 \pm 15,36^{a}$ & $85,90 \pm 11,37^{a}$ & $82,77 \pm 12,40^{\mathrm{a}}$ & $84,31 \pm 10,50^{a}$ \\
\hline $20 \mathrm{MST}$ & $78,45 \pm 7,65^{b}$ & $83,74 \pm 15,36^{a}$ & $85,99 \pm 11,38^{a}$ & $82,85 \pm 12,42^{a}$ & $84,43 \pm 10,52^{a}$ \\
\hline $21 \mathrm{MST}$ & $78,54 \pm 7,64^{b}$ & $83,84 \pm 15,37^{a}$ & $86,08 \pm 11,39^{a}$ & $82,99 \pm 12,43^{a}$ & $84,54 \pm 10,52^{a}$ \\
\hline \multicolumn{6}{|c|}{ Jumlah Tangkai } \\
\hline $18 \mathrm{MST}$ & $19,11 \pm 2,53^{\mathrm{ab}}$ & $16,84 \pm 2,73^{c}$ & $19,67 \pm 2,16^{\mathrm{a}}$ & $19,77 \pm 2,48^{a}$ & $18,69 \pm 2,56^{b}$ \\
\hline 19 MST & $19,11 \pm 2,53^{\mathrm{ab}}$ & $16,84 \pm 2,73^{c}$ & $19,66 \pm 2,13^{a}$ & $19,75 \pm 2,43^{a}$ & $18,69 \pm 2,56^{b}$ \\
\hline $20 \mathrm{MST}$ & $20,57 \pm 2,13^{a b}$ & $18,39 \pm 2,41^{c}$ & $20,92 \pm 1,60^{a}$ & $21,14 \pm 2,02 a$ & $20,10 \pm 2,24^{b}$ \\
\hline $21 \mathrm{MST}$ & $21,82 \pm 1,66^{b}$ & $19,97 \pm 2,09^{c}$ & $22,35 \pm 1,31^{a}$ & $22,61 \pm 1,73 a$ & $21,50 \pm 1,93^{b}$ \\
\hline \multicolumn{6}{|c|}{ Kerontokan Daun } \\
\hline $18 \mathrm{MST}$ & $1,41 \pm 0,50^{\mathrm{bc}}$ & $1,45 \pm 0,50^{b}$ & $1,63 \pm 0,49^{a}$ & $1,47 \pm 0,50^{b}$ & $1,29 \pm 0,46^{c}$ \\
\hline 19 MST & $1,41 \pm 0,50^{\mathrm{ab}}$ & $1,45 \pm 0,50^{\mathrm{ab}}$ & $1,63 \pm 0,49^{b}$ & $1,57 \pm 1,59^{a b}$ & $1,9 \pm 0,46^{a}$ \\
\hline $20 \mathrm{MST}$ & $1,38 \pm 0,49$ & $1,37 \pm 0,48$ & $1,38 \pm 0,4$ & $1,43 \pm 0,50$ & $1,38 \pm 0,49$ \\
\hline $21 \mathrm{MST}$ & $1,51 \pm 0,50^{b}$ & $1,50 \pm 0,50^{\mathrm{ab}}$ & $1,36 \pm 0,48^{a}$ & $1,41 \pm 0,49 a b$ & $1,42 \pm 0,50^{\mathrm{ab}}$ \\
\hline \multicolumn{6}{|c|}{ Diameter Batang Tanaman } \\
\hline $18 \mathrm{MST}$ & $6,23 \pm 5,56^{a}$ & $5,58 \pm 0,66^{b}$ & $5,42 \pm 0,69^{b}$ & $5,47 \pm 0,63^{b}$ & $5,68 \pm 0,57^{\mathrm{ab}}$ \\
\hline 19 MST & $6,16 \pm 5,57$ & $5,58 \pm 0,66$ & $6,00 \pm 6,64$ & $5,47 \pm 0,63$ & $5,66 \pm 0,59$ \\
\hline $20 \mathrm{MST}$ & $6,23 \pm 5,56$ & $5,66 \pm 0,68$ & $6,06 \pm 6,64$ & $5,56 \pm 0,63$ & $5,78 \pm 0,60$ \\
\hline $21 \mathrm{MST}$ & $5,70 \pm 0,60$ & $5,75 \pm 0,67$ & $6,15 \pm 6,63$ & $5,64 \pm 0,63$ & $5,90 \pm 0,60$ \\
\hline
\end{tabular}

G100 = dosis sinar gamma 100 gy, G200 = dosis sinar gamma 200 gy, G300 = dosis sinar gamma 300 gy, G400 = dosis sinar gamma 400 gy, G500 = dosis sinar gamma 500 gy. MST (Minggu Setelah Tanam). Superskrip yang berbeda pada baris yang sama menunjukkan berbeda nyata $(\mathrm{p}<0,05)$

\section{SIMPULAN}

Semakin tinggi dosis iradiasi sinar gamma memberikan pengaruh positif terhadap tinggi dan diameter tanaman lamtoro. Respon pertumbuhahn lamtoro pada cekaman kekeringan menunjukkan hasil terbaik pada 400 gy.

\section{DAFTAR PUSTAKA}

Fitri, DRK. 2010. Uji ketahanan tanaman cabai keriting (Capsicum annuum L.) hasil induksi mutasi dengan ethyl methane sulphonate (EMS) pada generasi kedua terhadap penyakit antraknosa. Jurnal Sains dan Teknologi 1:16-22

Hanafiah, DS, Trikosoeningtyas, Yahya S, \& Wirnas D. 2010. Induced mutations by gamma ray irradiation to argomulyo soybean (Glycine max) variety. Bioscience. 2(3):121-125.

Hoult EH \& Briant PP. 1974. Practice experiments and demonstration Dalam : Whiteman PC, Humpreys LR, Mounteith NH. A Course Manual in Tropical Pasture Science. Brisbane (AU) : Australia Vice Chancerllors Committee.

Herison, Rustikawati, Surjono HS \& Aisyah SI. 2008. Induksi mutasi melalui sinar gamma terhadap benih untuk meningkatkan keragaman populasi dasar jagung (Zea mays L.). Akta Agrosia 11(1):57-62.

Hoeman, S. 2007. Peluang dan potensi pengembangan sorgum. Workshop Peluang dan tantangan sorgum sebagai bahan baku . Jakarta (ID) : Departemen Pertanian

Sibarani IB, Lahay RR \& Hanafiah DS. 2015. Respon morfologi tanaman kedelai (Glycine max (L.) Merrill) varietas anjasmoro terhadap beberapa iradiasi sinar gamma. Jurnal online Agroekoteknologi 3 (2) : 515- 526.

Jones, DL \& Kochian LV. 1995. Aluminium inhibition of the inositol 1, 4 5-triphosphate signal transduction pathway in wheat roots: a role in aluminium toxicity. The Plant Cell. 7: 1913-1922

Purba, KR, Bayu ES \& Nuriadi I, 2013 Induksi mutasi radiasi sinar gamma pada beberapa varietas kedelai hitam (Glycine max (L.) Merrill). Jurnal online Agroekoteknologi 1 (2) : 154-165
Marschner, H. 1995. Mineral Nutrition of Higher Plants. London ( UK ) : Academic Press. London.

Metwally, S A, Awad. ARE, Leila BHA., Tayeb TAAE., \& Habba IEA. 2015. Studies on the effect of gamma, laser irradiation and progesterone treatments on gerbera leaves. Journal of Biophysiscs Egyptian. 3(6): 43-50

Nisa' F. 2020. Pengaruh radiasi sinar gamma Co-60 terhadap morfologi tanaman dan kadar protein kedelai varietas Gamasugen 2 (Glycine Max (L.) Marril). [skripsi]. Malang (ID) : Jurusan Fisika Fakultas Saintek UIN Malik Irahim Malang

Poespadorsono. S. 1998. Dasar-Dasar Pemuliaan Tanaman. PAU Institut Pertanian Bogor. Bo

Reksohadiprodjo, S. 1985. Produksi Tanaman Hijauan Makanan Ternak Tropic. Edisi Kedua.. Yogyakarta (ID) : BPFE Yogyakarta

Siregar, S.B. 1994. Ransum Ternak Ruminansia. PT. Penebar Swadaya, Jakarta.

Rici. 2009. Pengaruh Radiasi Sinar Gamma Terhadap Pertumbuhan dan Produksi Beberapa Varietas Kedelai (Glycine max L. Merril) pada Generasi Pertama. [skripsi]. Medan (ID): Fakultas Pertanian, Universitas Sumatera Utara.

Soeranto, H. 2003. Peran iptek dalam pemuliaan untuk mendukung industri pertanian. Dalam K. Abraham, Y. Arrianto, D.W. Nurhayati, Sujatmoko, R. Sukarsono, T.T. Basuki, A. Takazani, IGN J. Sarjono, T. Marjiatmono, Syarif, Sudianto, Samin, T. Tjiptono, dan D. Sujiko (eds.) Prosiding Pertemuan dan Presentasi Ilmiah Penelitian Dasar Ilmu Pengetahuan dan Teknologi Nuklir. Yogyakarta (ID): P3TM Batan.

Yasin N. 2006. Perkembangan hidup dan daya mangsa Cirunus coeruleus Muslant pada beberapa kutu tanaman. Jurnal Hama dan Penyakit Tumbuhan Tropika 6 (2): 79-86.

Yumiarty H \& Suradi K. 2010. Utilization of lamtoro leaf in diet on pet production and the lose of hair rabbit's pelt. Jurnal Ilmu Ternak.7(1): 73-77. 